\title{
The Rise and Fall of Victoria's Labour Market Reform
}

\author{
Ken Phillips
}

I n the 1993 West Australian and South Australian State elections, the leaders of the main opposition parties promised their electors that they would not 'do a Kennett'. They were referring, of course, to the Kennett Government's industrial-relations reforms introduced in Victoria in November 1992.

Victoria's Employee Relations Act is the first serious attack mounted in Australia against the established system of centralised wage-fixing. The Victorian reforms sparked massive umion opposition, chiefly in the form of public rallies. Despite such opposition, the Victorian Premier and his government continue to do well in the opinion polls.

The Victorian Department of Business and Employment regards the introduction of decentralised workplace legislation as 'an essential ingredient of the Government's commitment to provide a revitalised environment for Victorian business' (Doing Business In Victoria, 1993, p.25). The government wants to see the workplace culture change, arguing that businesses cannot compete with the rest of the world and create employment until labour markets are freed from the restrictions of the centralised system. If the Victorian legislation were to succeed in creating greater employment growth than in the other States, pressure to duplicate the success across Australia could be overwhelming. But is the hoped-for change in workplace culture occurring in the Garden State?

\section{The Employee Relations Act}

The Employee Relations Act, which took effect on 1 March 1993, abolished State awards and the State Industrial Relation Commission and replaced them with a system of voluntary employment agreements for employees falling under the State's industrial-relations jurisdiction (then about 40 per cent of the total). The legislation deems such employees (both existing and new) to have entered individual employment agreements, whose terms are the award conditions that applied under the previous system. But the Act allows employees to enter new agreements. These agreements may be collective or individual, but must include certain minimum

Ken Phillips is a Melbourne-based trade-union consultant and industrialrelations commentator. 
standards, such as four weeks annual leave, five days of sick leave annually, and maternity, paternity, adoption and long-service leave. Hourly pay rates cannot be lower than those applying under expired awards. But employees cannot be forced to enter new agreements. And contrary to the claims made by some unions, s.38(2) of the Act makes it clear that grievance cases can be taken to the State Employee Relations Commission not just by employers but also by employees or their representatives.

The legislation offers a workable set of minimum rules and has been taken up by some employers and employees. One such employer is the Sizzler chain of family restaurants, approximately 90 per cent of whose 1400 employees signed agreements offered to them by the company (Herald Sun, 26 September 1993). Yet the impact of the Act has been mainly psychological; only a small percentage of employees have signed agreements that effectively alter the terms of their previous State awards. The Act provides the legal structure for workplace reform but has not been followed by widespread actual reform.

\section{Federal Interference}

Two things have gone wrong. First, federal legislation has enabled Victorian workers to transfer to federal awards. The Employee Relations Act was introduced on the assumption that the Liberal-National coalition would win the Commonwealth election in 1993 and would introduce complementary legislation. In the event, the Keating Government was re-elected and introduced federal legislation enhancing the ability of unions to remove unionists from State jurisdiction and to seek federal coverage. As a result, few Victorian workers (potentially including State employees) are likely to be covered by State legislation by the end of 1994: Federal coverage is progressively undermining any impact the Employee Relations Act might otherwise have had on employment creation. However, should the High Court successfully challenge the right of the federal Industrial Relations Commission to transfer Stateemployed workers to their jurisdiction, the Victorian reforms will gain new momentum. A decision is expected in mid-1994.

The second problem has been the apparent inability of the Victorian government to implement its workplace reform agenda with its own employees. This has been a surprise. It could have been expected that, as the largest employer in the State, the Victorian government would attempt to entice its own employees into employment agreements, in order to demonstrate to private-sector employees and employers that its reforms could succeed. If large numbers of State employees had voluntarily signed employment agreements, the Kennett Government would have secured a major advantage in its reform drive. But it hasn't happened. The Victorian government's apparent lack of commitment to its own labour-market reforms contrasts starkly with the robust implementation of its other reforms. 


\section{The Public Sector Management Act}

The problem first appeared when the government, in Part 4 of its Public Sector Management Act 1992, introduced contracts for executive officers of the public service that exempted them from the provisions of the Employee Relations Act. The impact of this was twofold. First, it revealed that the State government differentiated between classes of employees, namely, management and workers. The Act was supposed to help break down cultural workplace barriers; but the government's apparent espousal of the 'them and us' mentality fuelled suspicions that the Act had a hidden agenda. Second, it eliminated any personal commitment on the part of senior public servants to employment agreements: the people on whom the government had to rely to implement the Employee Relations Act were not themselves covered by the Act.

This lack of commitment became apparent when certain employees of the Victorian Education Department requested employment agreements in 1993. The subsequent administrative muddle verged on the farcical. Along with the interested employees and their representatives, the Department developed a standard employment agreement. The six-page, plain-English agreement replaces the 54-page, convoluted award of the previous system, and facilitates significant managerial flexibility in workplace arrangements. Yet the Department did not then encourage its employees to sign up. Rather, over a nine-month period, a steady pattern of obstruction unfolded.

Employees who asked for agreements waited for up to eight weeks for copies to be sent for signing. Often they never arrived at all. When they did, they frequently contained errors; and correcting them could take many weeks. Some errors appeared to embarrass the department, and affected employees were subjected to abuse. Confidential agreements were mailed to the wrong employees, exposing those wanting agreements to ridicule and harassment. Line managers who were supposed to sign on behalf of the government did not receive briefings on the content or implications of agreements. Some line managers tried to talk employees out of signing and refused to sign when requested to do so by employees. Some employees had to wait for more than ten weeks for pay increases to which their agreements entitled them. In some cases, payments were made only after the employees threatened to invoke dispute-settling procedures. One employee who signed an agreement was subsequently subjected to intimidation, mysteriously disappeared from the Department's computer employment records, and was not paid for many weeks.

All this occurred at a time when employees who had faith in employment agreements were bearing the brunt of trade-union vilification and attack. Employee representatives willing to assist State employees in obtaining agreements have become cautious in pursuing requests. 


\section{The Teaching Service (Amendment) Act}

More recently, the Victorian Education Department has drawn up and imposed on school principals contracts under its Teaching Service (Amendment) Act 1993, which, like the Public Sector Management Act, creates exemptions from the provisions of the Employee Relations Act. Both the enabling legislation and the contract allow the employer to alter the terms, conditions and remuneration of school principals' employment unilaterally and at any time, including dismissal. Principals are prohibited from taking legal action against possible breach of contract. Interpretation of the contract is at the employer's discretion, and disputes under the contract are to be settled by an agent of the employer without any right of appeal to an independent adjudicator. Employee holiday leave, sick leave and long-service leave are not guaranteed, and parental and adoption leave are removed. The government is using its position to grant itself special employer rights that flout the principles of normal commercial contract.

In view of these strange events, and the State government's reluctance to allow its own employees to benefit from the Employee Relations Act, is it any wonder that the private sector has been slow to adopt the reforms?

The wider lesson to be learned from this debacle is that legislation alone is insufficient to effect labour-market reform. Reform is about changing attitudes, and is largely dependent on the attitude of employers to employees. To succeed, reforming governments will need to transform their own corporate culture before they can succeed in breaking down class consciousness among their own employees. 